\title{
A GAME AGAINST NATURAL SELECTION? HIBERNATION OF MIGRATORY BAT SPECIES IN THEIR SUMMERING RANGE IN EASTERN UKRAINE
}

\author{
Igor Zagorodniuk \\ National Museum of Natural History, NAS of Ukraine (Kyiv, Ukraine) \\ Correspondence to: I. Zagorodniuk; National Museum of Natural History, NAS of Ukraine; \\ Bohdan Khmelnytsky St. 15, Kyiv, 01030 Ukraine; e-mail: zoozag@ukr.net
}

\begin{abstract}
A game against natural selection? Hibernation of migratory bat species in their summering range in Eastern Ukraine. - I. Zagorodniuk. - A series of new findings of migratory bat species that in recent years formed wintering groups in the region are described. Bats were found in buildings within human settlements in all cases. Descriptions of new autumn and winter records of Nyctalus noctula in Gorlovka and Rubizhne, Vespertilio murinus in Luhansk, Alchevsk and Donetsk, and Pipistrellus cf. pygmaeus in Mariupol are presented. These findings are considered as further evidence of formation synanthropic bat communities in eastern Ukraine and expand the geographical boundaries of the known wintering range of these migratory species within Ukraine. Similar cases are rare so far, although they indicate new changes that may soon become regular. Cases of wintering are considered as "trial of forces" of a part of the population in the context of trading-off the "cost of migration" for the "cost of hibernation" under conditions of global warming as well as of improving wintering conditions in the region due to various artificial shelters, mainly in cities.
\end{abstract}

Key words: bats, Vespertilionini, hibernation, Eastern Ukraine, migration, evolution.

Гра проти природного добору? Випадки зимівлі видів-мігрантів кажанів в їхньому ареалі літування на сході України. - I. Загороднюк. - Описано серію нових знахідок видів, що є мігрантами в регіоні, проте останніми роками формують зимівельні групи. В усіх випадках кажанів виявлено в населених пунктах, в житлових приміщеннях. Наведено відомості про нові осінні та зимові знахідки Nyctalus noctula в Горлівці та Рубіжному, Vespertilio murinus в Луганську, Алчевську та Донецьку, Pipistrellus cf. pygmaeus в Маріуполі. Ці знахідки розглядаються як свідчення подальшого процесу формування синантропних угруповань кажанів на сході України і розширюють географічні межі відомого зимового ареалу цих видів-мігрантів в межах України. Поки подібні випадки є поодинокими, проте вони є індикаторами нових змін, які дуже скоро можуть стати закономірними. Такі випадки розглядаються як «проба сил» у частини популяції замінити «ціну міграції» на «ціну зимівлі» в умовах глобального потепління клімату і покращення умов зимівлі на місці за рахунок різноманітних штучних сховищ, зокрема й у містах.

Ключові слова: кажани, Vespertilionini, зимівля, східна Україна, міграція, еволюція.

\section{Introduction}

The current state of the fauna of Ukraine is characterized by significant dynamics of zonal faunal complexes and also by significant changes in geographical ranges and seasonal activity of a number of species that before had a rather limited presence in space and time. During the last century, the territory of Ukraine has changed by 4-26\%, depending on the region, and one of the most transformed regions is the east of Ukraine (Zagorodniuk, 2006). This region was and still remains an arena of powerful transformations of nature, which is related to both the strong industrialization in the first half of the 20th century, and to de-industrialization, which began in the early 21 st century and now reinforced by military actions. A number of synanthropic processes of the eastern fauna was revealed earlier (Zagorodniuk, 2012).

Among mammals, bats demonstrate distinct tendencies for synanthropy and, respectively, for noticeable changes in their status, distribution, and abundance (Zagorodniuk, Tkach, 1998). In fact, 
today bats are one of the most successful mammalian taxonomic groups showing clear synanthropy. The number records of bats in cities each year reveals distinct positive dynamics (Godlevska, 2012; Rebrov, 2014).

The present paper considers a group of typical migratory species that are represented in the region's fauna by species of the tribe Vespertilionini (Nyctalus, Vespertilio, and Pipistrellus species). Among them, winter records are known for two species, Nyctalus noctula and Vespertilio murinus, which are the main subject of this study.

The aim of this article is to summarize the data on findings of migratory species in eastern Ukraine beyond the breeding period, when normally populations should be located in wintering areas in other regions.

\section{Material and methods}

Data on bat records were amassed during 2005-2014 and used regularly in studies on the composition and changes of the fauna (e.g., Zagorodniuk, Korobchenko, 2008; Godlevska, 2012; Rebrov, 2014; Godlevska, 2015).

The two main data sources in the autumn-winter period were: 1) examination of bat shelters and, if necessary, extraction of bats for identification and rehabilitation, 2) analysis of residents' reports on findings and descriptions of bats in buildings and, if possible, photo-documentation of such records. Both sources were reliable due to the network of students and colleagues of the Faculty of Natural Sciences Faculty of the University of Luhansk and other educational institutions.

The network remained effective after 2013 (2014-2017) and we continue to receive phone calls and e-mails asking for advice. Some of these messages are valuable regarding formation on settled populations of migratory species. All cases are related to the wintering period, which lasts from autumn to early spring seasonal migrations, i.e. from October to late March (see Zagorodniuk, 2002).

\section{Records of Nyctalus noctula}

Currently more than 10 records during the non-reproductive period of this species are described in the region, all related to synanthropic locations, especially the multi-storey residential areas of large cities (Zagorodniuk, Rebrov, 2014). Earlier described locations (loc. cit.) generally coincided with the pattern of the summer range of the species in the region. They were confined to the settlements located along the valley of the Siverskyi Donets and its largest tributary, the main corridors for migratory species (Fig. 1).

New findings are from both the formerly known sites of this species' records (Siverodonetsk, Rubizhne, Konstiantynivka, Luhansk) and new locations. During all our research on bats in Luhansk Oblast (2000-2014), Nyctalus noctula was detected in post-reproductive period only in 7 of 15 years (2007-2008, 2010-2014) (Zagorodniuk, Rebrov, 2014).

Most of the records (about 10) are from Luhansk, mostly from the central part of the city, and two other records from Siverodonetsk. In particular, in Siverodonetsk one migration cluster was discovered in an empty apartment on 11 August 2013 (Zagorodniuk, Rebrov, 2014) and two autumnwinter findings on the ground near four-storey buildings: 1 specimen on 25 February 2011 and 5 specimens on 10 November 2011 (Godlevska, 2012).

Among the latest records, two important findings of this bat are from Yenakiieve, which is significantly distant from other findings, as well as one atypical finding of the species in Rubizhne.

1. Yenakiieve, 02.02.2016 (time of hibernation). The bat was found near a private ground- and one-storey building, but next to it was the 3-storey building of the hospital, which could serve as wintering shelter. The discovered specimen is a male, Fa $=50 \mathrm{~mm}$ (Fig. $2 a$ ). The animal was found on the street during the thaw, in daytime, on the asphalt. The bat was weakened hence it was rehabilitated (water, calm) and left to hibernate in a cardboard box. After 50 days, on 20.03.2016 the animal was found dead, mummified (O. Pronin, pers. comm. and photo). This finding is the most distant from all of the winter records of the species in the region and demonstrates the expansion of 
its wintering range. In Donetsk Oblast, this is the third described wintering location, after Konstantinovka (05.12.2011: Godlevskaya, 2012) ${ }^{1}$ and Kramatorsk (winter; Zagorodniuk, Rebrov, 2014) ${ }^{2}$.

2. Rubizhne, 15.08.2016 (end of autumn migration). The bat was found resting in an apartment on the 3th floor of a four-storey building in Rubizhne, in a collection of cacti completely stuck in the hooked thorns of Mammillaria bocasana (H. Olievska, photo and pers. comm.). The species identification was complicated because of the rather general photo of the animal, but eventually it was identified as Nyctalus noctula (L. Godlevska, pers. comm.). Among other things, this finding indicates that synanthropic bats in unnatural habitats face a new danger: the barbed protective covers of alien plants, including indoor succulents (Fig. $2 b$ ).

3. Pokrovske, before 02.2018 (probably end of autumn migration). The species of the bat was identified according to its accurately disembowelled skin that was found on the beam in the attic of the Palace of Culture. The skin was parchment-like and the limbs were dried. Numerous scraps of pigeons (Columba livia) were found nearby. In the author's opinion, the bat probably was a victim of Martes foina. The skin has no traces of moths or skin beetles, which affirms the late autumn or winter appearance of this specimen; this assumption is also supported by the typical resting pose of the mummy with bended limbs, i.e. the attack might happened in state of deepest hibernation of the bat (material obtained from A. Rott).
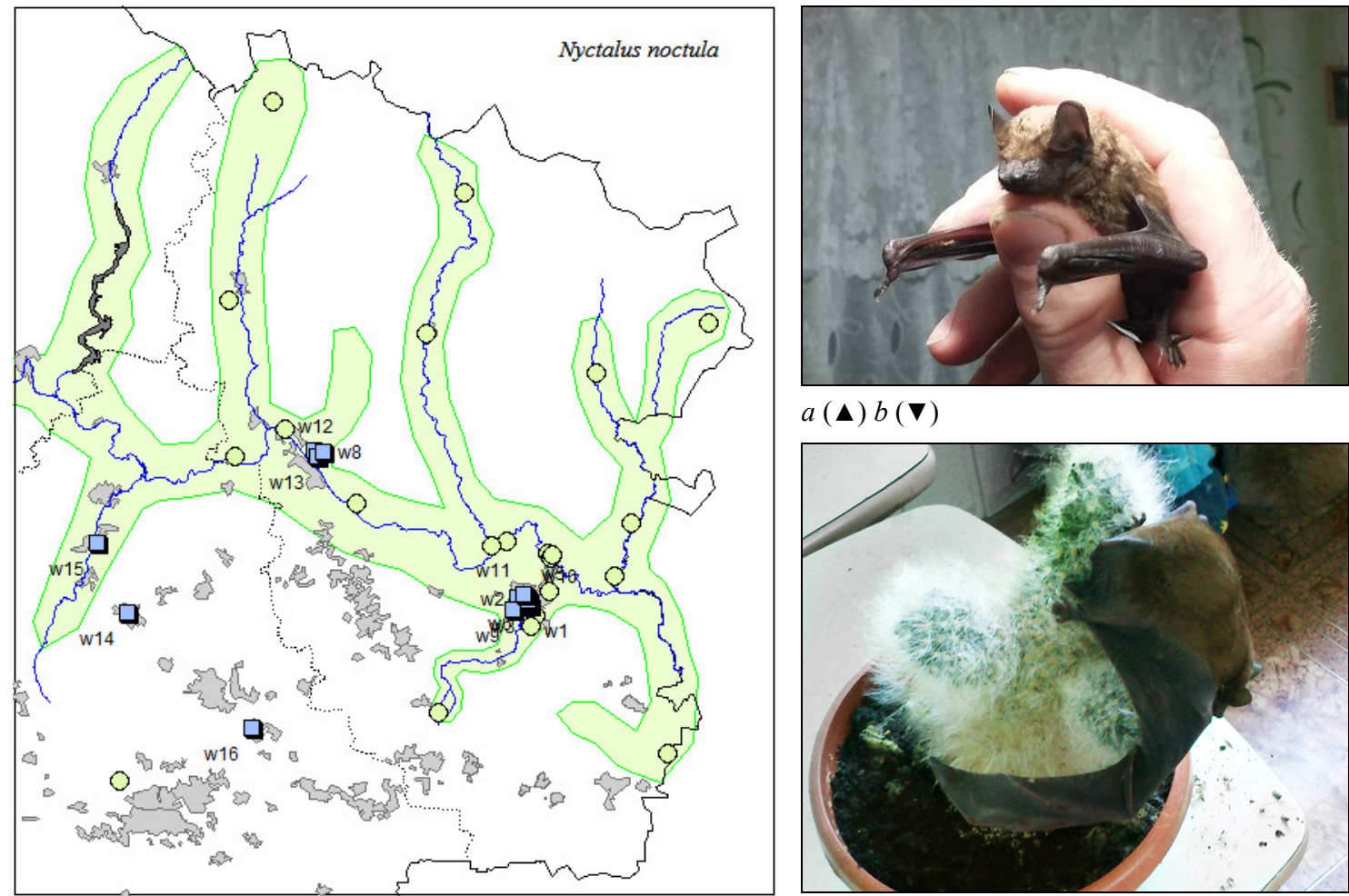

$$
a(\mathbf{\Lambda}) b(\mathbf{\nabla})
$$

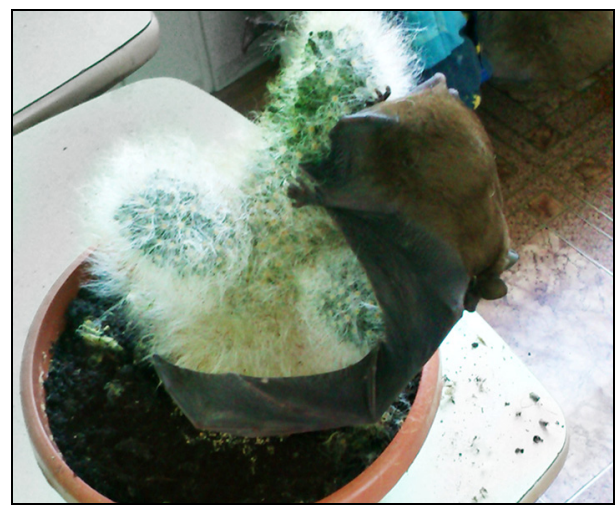

Fig. 1. Records of Nyctalus noctula in eastern Ukraine (Zagorod- Fig. 2. General view of the noctule bats found niuk, Rebrov, 2014, with additions). Winter records are indicated in February 2016 in Yenakiieve ( $a$, by A. Prowith numbers (w16 and w17 are new records from Yenakiieve and nin) and in August 2016 in Rubizhne (b, by Pokrovske); the shaded area shows the summering range (loc. cit.). I. Oliyevska).

Рис. 1. Знахідки Nyctalus noctula на сході України (за: Загород- Рис. 2. Загальний вигляд вечірниць, знайденюк, Ребров, 2014, $з$ доповненнями). Зимові знахідки подано з них у лютому 2016 р. в Снакієвому ( $a$, автор номерами (w16 та w17 - нові знахідки в Снакієвому та По- О. Пронін) та в серпні 2016 р. в Рубіжному кровському); заливка — літній ареал (loc. cit.). (b, автор I. Олієвська).

\footnotetext{
${ }^{1}$ Subsequently, in 2015, this locality was reissued as a new one (Godlevska, 2015).

${ }^{2}$ Detailed information was lost: cited article was finished in state of our evacuation from Luhansk occupied by the Russian invaders. Probably one of the sources was the "Red Book" of Kramatorsk Park (Solomashenko, 2010).
} 


\section{Records of Vespertilio murinus}

A plenty of new data mainly based on sound signals suggests the presence of this species in the region during the autumn-winter period. Data continue to be reported by colleagues who also participated in the bat census in late autumn in Luhansk in 2005-2014. Particular attention is paid here to the findings of the bats themselves, which were passed on by locals concerned about these animals.

Based on the distribution of known records in space and time, $V$. murinus in the east of Ukraine seems to be not typical for summer bat communities and appears here mainly during seasonal migrations from more northern regions (Zagorodniuk, Korobchenko, 2008).

Periods of vocalization. Previously, a number of records of this species have been described based on the registration of lekking males (Zagorodniuk, 2006; Zagorodniuk, Korobchenko, 2008; Zagorodniuk, Zaika, 2009). Analysis of these data allows suggesting certain regularities. Relatively long periods of time fall out during the four years of observation (mainly in Luhansk): 1) during 2005, in Luhansk, lekking was recorded on the extreme dates 29.10.2015 and 26.11.2015, i.e. lekking lasted a month (4 weeks); 2) during 2006, in Luhansk, the extreme dates were 10.11.2006 and 28.11.2006 (i.e., lekking lasted 3 weeks), 3) during 2006, in Lysychansk, - from 10.11.2006 to 02.12.2006, i.e., lekking lasted not less than 3 weeks; 4) during 2009, in Luhansk, for three dates with a span of at least 3 consecutive weeks between them: 13.11.2009, 19.11.2009, and 04.12.2009. Generally, turns out that the lekking period lasts about 3-4 weeks. At the same time, the number of records in a decade increases gradually from the beginning of the period of the transaction to its end and then it breaks down. We can assume that the growth of lekking (reproductive) activity, although stimulated by the first strong cooling and the first thaw, grows until stable colds and, actually, the cooling stops it.

Actual findings are much rarer than voice records. In addition to the already described findings (Zagorodniuk, Korobchenko, 2008), we have three new ones:

1. Luhansk, 22.11.2012 (the beginning of hibernation). The species was found in the northern outskirts of Luhansk (Quarter of the 50th Anniversary of October) at the end of October 2012, i.e. in the period when autumnal lekking of males occur in this city (Zagorodniuk, Korobchenko, 2008). A bat was found near a four-storey building, on the 4th floor of which replacement of windows was in progress (O. Uzun, pers. comm., photo and video of the bat; Fig. 3 b). On the same day, 22 November 2012, after the photo was taken, the bat escaped and lived in a room in cavities under the false ceiling showing activity every midnight. Within a few days (until 02.12.12) it was caught and released. The sex of the animal was not checked, while the length of its forearm (after reconstruction from the photo) is ca. 45-50 mm. Evidently, the record of $V$. murinus from Luhansk on 22.11.2012 published without details (Godlevska, 2013) refers to the same specimen that is described here.

2. Alchevsk, 16.02.2014 (strong frosts). The bat was found on the asphalt on 5-7 February 2014 , it was warmed up in a box and handed over to rehab "in the state of hibernation", but actually it was dead. The specimen was an adult female, $\mathrm{FA}=44.9 \mathrm{~mm}$, collection number Z-1002 (working collection of the author). A series of photos was taken, both of general view and details (tragus, postcalcar lobe). This is one of the very first records of $V$. murinus females during late winter in the east of Ukraine, although there is a late autumn record from Donetsk (31.10.2016).

3. Donetsk, 10.04.2014 (the end of hibernation). A message about the discovery came from a student hostel; bat was found in a room on 10 April 2014 (Fig. 3 c). The correspondent (student Zhenia) reported that the bat was found by accident, in a corner with unfinished speeches, however, most likely, it was not wintering there (it was a rather a dry place), but the animal found a hiding place there during the recent thaw, in warm spring evenings. Following our advice, the bat was fed and released. No information about sex and forearm size was recorded.

4. Donetsk, 31.10.2016 (the beginning of hibernation). A bat was found in the late October 2016 in a yard among flats, apparently attacked western jackdaws (Corvus monedula). The animal was hissing trying to scare the birds; drops of blood were on its wings. 

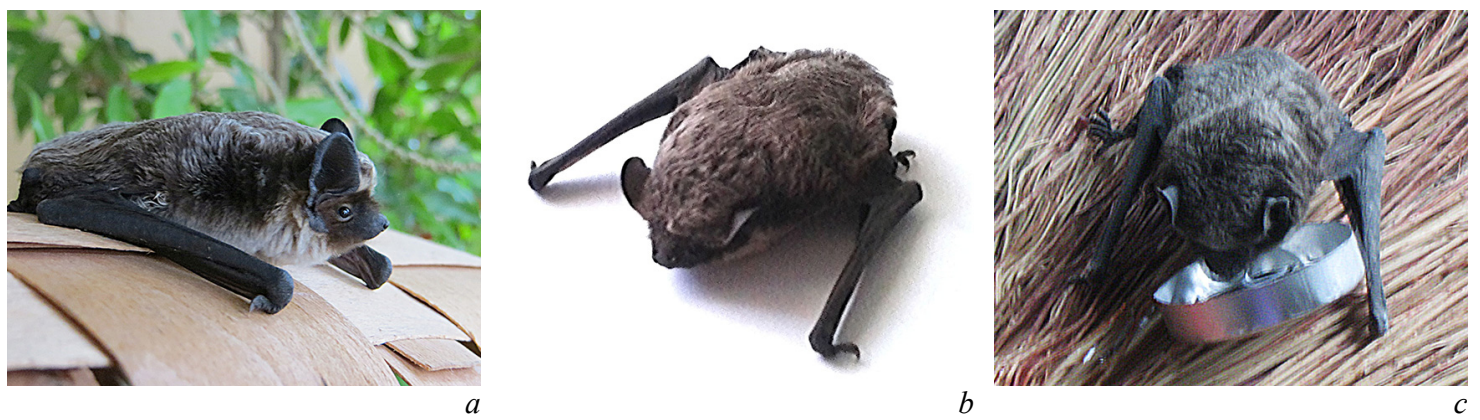

Fig. 3. General view of Vespertilio murinus discovered in wintering time in synanthropic sites in eastern Ukraine: $a$ - a bat found on 03.11.2016, Donetsk; $b$ - a bat found in a state of hibernation on 22.11.2012 near a five-storey building in Luhansk (quarter 50 Years of October); $c$ - a bat found in the economic corner of a dormitory in Donetsk 10.04.2014.

Рис. 3. Загальний вигляд лилика двоколірного (Vespertilio murinus), виявленого в період зимівлі в синантропних місцезнаходженнях сходу України: $a$ - кажан, виявлений 3.11.2016 р. в Донецьку; $b$ - кажан, виявлений 22.11.2012 біля багатоповерхівки в м. Луганськ (кв. 50-річчя Жовтня); $c$ - кажан, виявлений у господарському кутку студентського гуртожитку 10.04.2014 в м. Донецьк.

Characters of this individual: weight $14 \mathrm{~g}, \mathrm{FA}=4 \mathrm{~cm}$, female (Fig. $3 a$ ). The bat was given water to drink, on the third day fed with zophobas and subsequently kept in captivity for 9 days, until 09.11.2016, when warmer evenings arrived, and then released (pers. com. and photos from O. Pakter). The value of this finding is that it is a female, well fed and ready for wintering; usually in the autumn only males of the species are found (see also the above finding No. 2). In addition, this is the first actual record of this species in the winter in Donetsk.

\section{Records of Pipistrellus cf. pygmaeus}

The status of pipistrelles in the region is quite specific. Previously, the common pipistrelle and Nathusius's pipistrelle were described in this region. However, in fact, only the soprano pipistrelle ( $P$. pygmaeus) and the Kuhl's pipistrelle ( $P$. kuhlii) are known to author, and in some locations $P$. nathusii as well, one of the rarest bat species in the region". Both "common" species (kuhlii and pygmaeus) are alien in the regional fauna and are unknown in natural shelters: P. pygmaeus takes refuge in a variety of "small architectural forms" (forest houses, cabins, houses, water towers), while $P$. kuhlii occurs constantly ${ }^{4}$ in buildings of different types (kindergartens, multistorey buildings, various window openings). Survey of records of pipistrelles in synanthropic shelters was published by S. Rebrov (2012). Thus, only one settled species of the genus Pipistrellus is relatively abundant in fauna of the region, as well as one migratory species - the soprano pipistrelle (P. pygmaeus), but it has all signs of an alien species.

Mariupol, 11.12.2012. The soprano pipistrelle (Pipistrellus $\mathrm{cf}$. pygmaeus) was discovered during the processing of data on the finding of a wintering group of bats in Mariupol city. During the dismantling of window blocks on the 2nd floor of the Mariupol Regional Museum, a group of bats was discovered. The analysis of photographs and descriptions (O. Shakula, pers. com. and photos) showed that that group consists of about 50 specimens of $P$. kuhlii. Among them, one specimen was significantly smaller than $P$. kuhlii and clearly dark coloured (which is clearly visible on the photo of

\footnotetext{
${ }^{3}$ One record (q) was in Kreminna near the Klishnia lake (30.06.2001), another one ( + ) — in the Rih tract of Prydintsivska Floodplain Reserve (05.07.2001) (Petrushenko et al., 2002), and a third one ( $\left.\delta^{\Uparrow}\right)$ at the Novo-Illienko Biostation, 04.07.2009. For comparison, during 10 years of working in eastern Ukraine the author of this paper examined about 500-700 specimens of $P$. pygmaeus, 150-250 of $P$. kuhlii, and only 3 of $P$. nathusii, but not any $P$. pipistrellus. In the NNPM collection, there are several samples of $P$. pipistrellus, which findings were repeatedly published (e.g., Kondratenko, 2001), but subsequently re-identified as P. pygmaeus (including Novo-Illienko).

${ }^{4}$ This pipistrelle is not a seasonal migrant, although most of the records are concerned with this very species. One report differs from the others and it is related to the location where the species had not been recorded earlier hence we present it with details.
} 
the entire group placed into a cardboard box). Apparently, it was a different species: given the possible set of species known in the region it could be only P. pygmaeus. This finding clearly refers to the wintering period. The appearance of soprano pipistrelle (and in general the pipistrelle from the group pipistrellus-pygmaeus-nathusii) in hibernated colony of Kuhl's pipistrelle is a unique fact.

\section{Discussion}

Several important aspects of our knowledge on winter bat records may affect the value of species for further research, as well as for the development of several scientific hypotheses. In particular, for the hypothesis of regular attempts of migratory bats to remain in places of summering, which, under favorable conditions, can lead to the formation of a settled population. Obviously, due to the respondents, we record only a very small portion of hibernating individuals, probably less than $1 \%$, and there are incomparably more such cases.

\section{Is there an expansion of bat ranges or our knowledge?}

Until 2000, special studies on bats were not conducted in this region. In fact, research was started only in the late 1990s by a research group, in which the author also participated. Therefore, it is possible that new findings only confirm the presence of species that actually existed here for a long time. However, the reconstruction, including the comparison of descriptions of the fauna of Luhansk region in the review of I. Sakhno (1963) with modern data (Zagorodniuk, 2012 b), suggests that certain species, including bats (in particular Eptesicus serotinus s. 1. and Pipistrellus kuhlii) have appeared in the region recently. The same alien status should be recognized also for P. pygmaeus, which is known only from anthropogenic shelters.

Obviously, facts of formation (or existence) of local wintering ranges in migratory species should be discussed carefully. It is possible that a part of the population can remain on the ground year-round. In addition, the migratory status may not be obligatory. However, all cases of wintering in migrants are associated with synanthropy, although such facts were not discovered and collections of winter records of these species are absent as well. We can therefore suggest that the absence of findings evidence the absence of hibernation in cities. Moreover, the number of winter records of migratory bats has been clearly increased over the past 20 years, as noted in the recent analysis of winter findings of Nyctalus noctula (Zagorodniuk, Rebrov, 2014). A similar pattern can be seen in the analysis of the frequency of winter records of migratory bats in Ukraine, as shown for Vespertilio murinus (Godlevska, 2013) and N. noctula (Godlevska, 2015).

Thus, the process of synantropy and expansion of winter habitats, as well as the increase in frequency of winter finds of bats, which until recently were obligated migrants (or they were distributed beyond the region), occur objectively in eastern Ukraine. Increase of records occurs especially in large and medium-sized cities with multi-storey buildings and available warm shelters (balconies, windowsills, elevator shafts, utility rooms). At the same time, many technological premises in industrial facilities remain unexplored.

\section{What is growing: the number of bats or the frequency of registrations?}

Obviously, the significant distribution of knowledge about bats and the needs of their protection, the creation of web pages and booklets, organization of such events as "Year of bats" and "Bat's Night", as well as publications and discussions in the mass media (in which the author actively participated) significantly affected the growing of interest to these animals and the emergence of a series of new important messages about findings of bats from amateurs to specialists. Probably the proliferation of the Internet and mobile communications also contributed. However, bats did not become more numerous in the region, and their populations were mainly reduced due to destruction of natural shelters, changes in the food base, etc. Comparison of data from districts that differ in urbanization levels and data from respondents of different age and social groups suggests that the frequency of migrant bat records (i.e., the proportion of actual populations) in synanthropic habitats clearly increases. Moreover, both elderly and younger people are surprised by the new facts of such more and more frequent registrations. 
Thus, it can be assumed (a general impression, without statistics) that the increase in the frequency of registration of bats in synanthropic locations is an objective process caused by the specifics of both the development of urban landscape and synanthropic faunas (Zagorodniuk, $2012 \mathrm{a}$ ). In addition, such changes and their effects on the fauna are definitely more powerful and significant than the processes described in the framework of the concepts of global warming, although it is obvious that warming also has a significant impact.

\section{Can trends change due to current deindustrialization?}

Military actions that have been taking place in the east of Ukraine since the spring of 2014 caused significant changes not only in nature management (reduction of anthropogenic pressure on natural complexes, absence of hunting), but also the structure of natural complexes (violation of soil and vegetation cover, destruction of woodlands, changes of hydroregime). The largest current changes occur in synanthropic locations, which is due to the termination of a significant number of industrial objects and often their dismantling, an increase in the portion of objects that lost their economic value and maintenance (including cleaning and heating). All these processes lead to essentially unpredictable changes, although along with the increase of shelters available for bats. Buildings are attractive as places for rest and reproduction, with minimal anthropogenic pressure and small influence of predators. In addition, human buildings have an attractive temperature regime.

Therefore, deindustrialization may be considered as a positive factor for further synanthropization of populations, of essentially synurbic (i.e., susceptible to artificial urban landscapes and microclimate) animals, including bats. On the other hand, obtaining new data on the fauna of the region since 2014 has been largely limited by the impossibility of conducting field research and the gradual loss of contacts with residents and of residents' interest to the objects of nature.

All these three factors can contribute to the development of synanthropic bat communities.

\section{About the growth of the number of registrations}

The increase in the number of bats' registrations in cities that has taken place in recent years is probably due to the growing interest in research and active distribution of knowledge about bats among townspeople with requests to report bat records. The activity of "contact centres on bats", one of which - the "Donbas", led by the author of this publication (along with M. Korobchenko, M. Kolesnikov and S. Rebrov) - was precisely related to the identification of such cases and distribution of knowledge about the needs of the protection of these animals. However, it was not only the growth of research interest: numerous facts of meetings with bats in buildings also indicate the growing interest of bats to dwellings. Changes in ecosystems and forms of nature taking place in recent years suggest a further increase in cases of occurrence of bats in artificial shelters. Nonetheless, the interest of people to bats from people in eastern Ukraine has clearly faded in the recent years, and during 2014-2017 the author received from the east only 20-30 phone calls per year.

This fact explains the decrease in the media coverage of the topic: if in 2005-2014 there were at least 5-10 different reports on the local (oblast) television and somewhat more in the press, but now data can be obtained only after an extensive search for information on the Internet, as well as by preservation of a unique network of respondents and constantly reminding them about bats and other animals. This approach was also used in data collection for this article.

\section{Is there something Darwinian involved?}

Bats are mammals, and therefore, unlike other groups that also form migratory populations, they have a more complex and plastic behaviour. Bats seem to be able to change their migratory status faster than other animals. The numerous artificial and very diverse microclimatic conditions, the degree of comfort in shelters, as well as the general warming of cities are important factors in changing the migratory status. It is worth remembering that, in addition to global changes, there are processes of energetic warming of cities. All this creates the preconditions for the appearance of seasonal synurbic animal population.

Synurbization contributes to the change of migratory behaviour and appearance of stationary groups further affected by selective pressure upon at least the following 6 positions: 
1) bats that successfully wintered under synanthropic conditions are the first that occupy the most suitable summer shelters, while migrants are still passing through migratory routes;

2) such bats do not waste large amount of energy for migration and do not face the risks of death due to predators or extreme climatic conditions on long migratory routes;

3) since individuals of both sexes of the last year offspring can stay for wintering, bisexual wintering groups can be formed and subsequently exist as summer bisexual colonies, unlike typical maternity ones, which are usually present (Nehoda, 2002) at our latitudes;

4) the next year offspring may not migrate to the traditionally recognized wintering range and stay with the already settled groups becoming a new generation of a non-migrating colony;

5) subsequently, subpopulations can be formed with some level of genetic isolation between migratory and settled colonies;

6) since migratory status is a species trait, especially in bats of temperate latitudes, such rapid and large-scale changes on the level of population groups (and not separate individuals) can be preconditions for more significant microevolutionary events even up to possible speciation.

Today, we have a large number of examples of synanthropy among bats, often seasonal, and especially winter. Many species also demonstrate their expansion into new geographical regions, especially through the network of synanthropic locations (the common and Khazar serotines, soprano and Kuhl's pipistrelles, parti-coloured bat and grey long-eared bat). The winter finds of migratory bats described here are a logical manifestation of attempts of migratory species to wintering within their summering range, without the cost of migration to long distances and without the risks of death during migration. Obviously, such attempts of colonies to remain in summering places are a normal reaction to changes in the macroclimate of cities and in the set of available shelters.

Many researchers, including the author of this publication, when first face similar facts of wintering, they consider them as occasional events ending with the death of individuals, i.e. a deviation from the norm immediately eliminated by natural selection. However, research results presented in this paper allows suggesting that these processes can involve an essential part of the population and lead to microevolutionary processes eventually resulting in changes of both of the species and communities. Therefore, this "game" seems to be not against but controlled by selection.

\section{Acknowledgement}

I thank to the respondents for valuable information about findings of bats, in particular I. and H. Oliyevska (Rubizhne), O. Uzun (Luhansk), O. Pronin (Yenakiieve), O. Packter (Donetsk), O. Shakula (Mariupol), A. Rott (Pokrovske). My thanks to M. Kolesnikov and S. Rebrov (Luhansk University) for their ongoing support in the examination of locations, trips to places of detection of bats and participate in creating a database of bats records in the Luhansk region.

My thanks to V. Parkhomenko for editing the photographs and L. Godlevska for helping to identify of some samples. Thanks to A.-T. Bashta for useful comments, and Z. Barkaszi and D. Vishnevsky for the discussion of ideas.

\section{References}

Gazaryan, S. V., G. B. Bakhtadze, A. V. Malinovkin. 2010. Current state of knowledge of bats in Rostov region. Plecotus et al., 13: 50-58. (In Russian)

[Газарян, С. В., Г. Б. Бахтадзе, А. В. Малиновкин. 2010. Современное состояние изученности рукокрылых Ростовской области. Plecotus et al., 13: 50-58.]

Godlevska, L. V. 2012. Results of the work of the bat contactcentre (Ukraine). Scientific Notes of Taurida National University. Series: Biology, Chemistry, 25 [64] (4): 12-20. (In Russian)

[Годлевская, Е. В. 2012. Результаты работы контактцентра по рукокрылым (Украина). Ученые записки Таврического национального университета. Серия: Биология, химия, 25 [64] (4): 12-20.]
Godlevska, L. V. 2013. New Vespertilio murinus (Chiroptera) winter records. An indication of expansion of the species' winter range? Vestnik zoologii, 47 (3): 239-244.

Godlevska, L. V. 2015. Northward expansion of the winter range of Nyctalus noctula (Chiroptera: Vespertilionidae) in Eastern Europe. Mammalia, 79 (3): 315-324.

Kondratenko, A. 2001. Bats of the steppe districts of Luhansk region. Migration Status of Bats in Ukraine. Kyiv, 8-20. (Novitates Theriologicae; Pars 6). (In Russian)

[Кондратенко, А. 2001. Рукокрылые степных районов Луганщины. Міграційний статус кажанів в Украӥні. Київ, 8-20. (Novitates Theriologicae; Pars 6).]

Nehoda, V. 2002. Sexual pattern in populations of Pipistrellus nathusii and P. pipistrellus in Ukraine. Visnyk of the Luhansk 
Pedagogical University. Biological Sciences, No. 1 (45): 119-120. (In Ukrainian)

[Негода, В. 2002. Статева структура популяцій нетопирів Pipistrellus nathusii та P. pipistrellus в Україні. Вісник Луганського державного педагогічного університету. Біологічні науки, № 1 (45): 119-120.]

Petrushenko, Ya., L. Godlevska, I. Zagorodniuk. 2002. Investigations on bat communities in the Siversky Donets floodlands. Visnyk of the Luhansk Pedagogical University. Biological Sciences, 1 [45]: 121-124. (In Ukrainian)

[Петрушенко, Я. В., О. В. Годлевська, І. В. Загороднюк. 2002. Дослідження населення кажанів в заплаві Сіверського Донця. Вісник Луганського держсавного пед. університету. Біологічні науки, 1 [45]: 121-124.]

Rebrov, S. 2012. Records of the pipistrelle bats (Pipistrellus) in Luhansk region in the shelter of anthropogenic origin. Theriofauna of Protected Areas and Mammal Protection. Ukr. Theriol. Soc., Hola Prystan, 60. (Novitates Theriologicae; Pars 8). ISBN 978-966-1510-81-3. (In Ukrainian)

[Ребров, С. 2012. Знахідки нетопирів (Pipistrellus) на Луганщині у сховищах антропогенного походження. Tepiофауна заповідних територій та збереження ссавців. Укр. теріол. тов-во, Гола Пристань, 60. (Novitates Theriologicae; Pars 8).]

Rebrov, S. V. 2014. Research and bat protection in the Luhansk region (outcome of the regional branch of UCEBA). Scientific Research of Youth. Taras Shevchenko Luhansk National University. Luhansk, No. 5: 146-151. (In Ukrainian)

[Ребров, С. 2014. Дослідження та охорона кажанів на Луганщині (підсумки роботи регіонального осередку УЦОК). Науковий пошук молодих дослідників. Луганський національний університет імені Т. Шевченка. Луганськ, № 5 (Природничі науки): 146-151.]

Sakhno, I. I. 1963. Overview of mammalian fauna of Luhansk region. Reports at the Scientific Session Devoted to the Results of R \& D for 1962. Luhansk State Pedagogical Institute, Physical-Mathematical and Natural-Geographical Faculties. Luhansk, 49-54. (In Russian)

[Сахно, И. И. 1963. Краткий обзор фауны млекопитающих Луганской области. Доклады и сообщения на научной сессии, посвященной итогам НИР за 1962 год. Луганский гос. педагогический институт. Физ.-мат. и ест.геогр. факультеты. Луганск, 49-54.]

Solomashenko, Yu. V. 2010. Order Bats. On the Pages of the Red Data Book of Kramatorsk (Animal World). Reference and Guide. Kramatorsk, 75-85.

[Соломашенко, Ю. В. 2010. Отряд Рукокрылые. По страницам Красной книги г. Краматорска (Животный мир). Справочник-путеводитель. Краматорск, 75-85.]

Zagorodniuk, I. V., V. V. Tkach. 1996. The present state of fauna and the historical changes of abundance of the bats (Chiroptera) in the territory of Ukraine. Reports of the NAS of Ukraine, No. 5: 136-142. (In Ukrainian)
[Загороднюк, І. В., В. В. Ткач. 1996. Сучасний стан фауни та історичні зміни чисельності кажанів (Chiroptera) на території України. Доповіді НАН України, № 5: 136-142.]

Zagorodniuk, I. 2006. Mammals of eastern provinces of Ukraine: composition and historical changes of the fauna. Mammal Fauna of Eastern Ukraine. Luhansk, 216-259. (Proceedings of the Theriological School; Vol. 7). (In Ukrainian) [Загороднюк, I. 2006. Ссавці східних областей України: склад та історичні зміни фауни. Теріофауна сходу $У_{\kappa-}$ раїни. Луганськ, 216-259. (Праці Теріологічної Школи; Вип. 7). ISBN 966-02-3985-8.]

Zagorodniuk, I., M. Korobchenko. 2008. Rare fauna of eastern Ukraine: composition and distribution of rare species. Rarity Mammal Fauna and Its Protection. Luhansk, 107-156. (Proceedings of the Theriological School; Vol. 9). (In Ukrainian) [Загороднюк, I., М. Коробченко. 2008. Раритетна теріофауна східної України: їі склад і поширення рідкісних видів. Раритетна теріофауна та їі охорона. Луганськ, 107-156. (Праці Теріологічної школи; Вип. 9).]

Zagorodniuk, I., S. Zaika. 2009. New data on the distribution of rare bat and rodent species (Chiroptera et Rodentia) in Luhansk region, Eastern Ukraine. Vestnik zoologii, 43 (6): 564. (In Ukrainian)

[Загороднюк, I., С. Заїка. 2009. Нові дані про поширення рідкісних видів кажанів та гризунів (Chiroptera et Rodentia) на Луганщині, східна Україна. Вестник зоологии, 43 (6): 564.]

Zagorodniuk, I. 2012 a. Alien animal species in synanthrope sites of Luhansk Region. Dynamics of Biodiversity 2012. Luhansk University Press, Luhansk, 86-92. ISBN 978-966617-297-9. (In Ukrainian)]

[Загороднюк, I. 2012. Чужорідні види тварин у синантропних місцезнаходженнях Луганщини. Динаміка біорізноманіття 2012. Вид-во Луганського університету, Луганськ, 86-92. ISBN 978-966-617-297-9.

Zagorodniuk, I. 2012 b. Mammals of the Eastern Ukraine: changes in species list and abundance since I. Sakhno review (1963) to now. The Journal of $V$. Karazin Kharkiv University. Series: Biology, 16 (1035): 97-108. (In Ukrainian)

[Загороднюк, I. 2012. Ссавці сходу України: зміни переліку й рясноти видів від огляду I. Сахна (1963) до сучасності. Вісник Харківського начіонального університету імені В. Каразіна. Серія: Біологія, 16 (1035): 97-108.]

Zagorodniuk, I., S. Rebrov. 2014. Pattern of geographic distribution of Nyctalus noctula (Mammalia: Chiroptera) in eastern Ukraine and the formation of new hibernating groups in urban landscapes. Visnyk of the Lviv University. Series Biology, 67: 138-147. (In Ukrainian)

[Загороднюк, I., С. Ребров. 2014. Структура ареалу Nyctalus noctula (Mammalia) на сході України та формування нових зимівельних груп в урболандшафті. Вісник Львівського університету. Серія Біологічна, 67: 138-147.] 